\title{
Tidal and diel fluctuations in abundance of meiobenthic copepods on an intertidal estuarine sandbank
}

\author{
Geoffrey R. F. Hicks \\ Museum of New Zealand Te Papa Tongarewa, PO Box 467, Wellington, New Zealand
}

\begin{abstract}
Short-term changes in the population density of 2 abundant species of sand dwelling meiobenthic copepod and the population structure of the dominant species have been investigated in a New Zealand estuary. Samples were collected every $2 \mathrm{~h}$ for $24 \mathrm{~h}$ in a sampling regime that spanned 2 tidal cycles and 1 day/night cycle. Average sediment densities of Parastenhelia megarostrum were higher during periods of exposure than during periods of cover by tidal waters. Mean abundance of juveniles (copepodites) and adult males differed significantly in relation to the state of the tide. Females with and without egg sacs only indicate day/night differences at low tide. There were no tidal or diel differences in abundance for the interstitial species Paraleptastacus sp. For $P$. megarostrum, it is suggested that sediment abundance variability is tidal current flow/body size interactive. While the role of passive erosion is clearly important, it is argued that behavioural factors might also predispose copepodites to resuspension in the overlying water column. Diel differences in abundance of adult females may indicate a response to changes in patchiness of presumed autotrophic food resources.
\end{abstract}

\section{INTRODUCTION}

Variation in population density of meiobenthic taxa has traditionally been investigated over time scales of months, where analysis of seasonal events has been the objective. Longer term investigations extending over many years are rare, but those that have been undertaken have demonstrated consistent annual periodicities, yet with a high level of interannual stability (Heip 1979, 1980, Coull 1985a, b). These long-term studies provide an essential database whereby predictions may be made about what controls the subject species and are valuable when considering broader issues such as global change phenomena. We still, however, lack an understanding of very short-term periodicities that are more closely approximated to the life cycle time frames of meiofaunal organisms themselves.

The dominant environmental cues operating over a time scale of hours are tidal and day/night cycles. A number of workers have addressed issues in relation to tidal (e.g. Bell \& Sherman 1980, Palmer \& Brandt 1981, Fleeger et al. 1984, Decho 1988, Hicks 1988) or diel events (e.g. Boaden \& Platt 1971, Armonies 1988, 1989, Walters 1988), but in each case the time course of sampling has been either too constrained or too irregular to determine the magnitude or frequency of any inherent cyclic phenomena. Regular, short-term sampling of emergent meiofauna from subtropical sites has been undertaken over diel periods by Jacoby \& Greenwood (1988, 1989) and Walters (1991), but these authors have not evaluated meiofauna in sediments relative to state of the tide. The only studies to integrate tidal and diel variability in abundance of meiofaunal taxa using repetitive and replicative sampling techniques are those of Coull \& Feller (1988) and Feller et al. (1990). The former authors collected meiobenthic copepods every $2 \mathrm{~h}$ for $24 \mathrm{~h}$ at 3 muddy sites in a South Carolina (USA) salt marsh. Their major findings were that total copepod abundance peaked during daytime low tide at all 3 sites, but that in only 2 of the 8 species included was there a clear tide effect on abundance. They went on to suggest that there would be little exchange of individuals between habitats as tidal levels changed. In none of the above studies has it been established if all life history stages of a species are influenced in the same way by changes in tidal or light regime.

In Pauatahanui Inlet, New Zealand, intertidal sandbanks are dominated by the meioepibenthic harpac- 
ticoid copepod Parastenhelia megarostrum. This copepod attains extremely high abundances in the troughs of mobile sand ripples and a substantial database now exists on its population biology. In an attempt to determine the swimming potential of this species, experiments using emergence traps showed that, unlike members of an adjacent seagrass copepod assemblage, $P$. megarostrum did not actively emerge from the sediment and undertake bouts of swimming activity during high tidal periods (Hicks 1986). Evidence from this and other studies (Hicks 1984, 1988) strongly suggests that this species, in particular young stages of the population, has great fidelity to sediment particles.

Much has recently been written on the influence of hydrodynamic processes on meiofaunal organisms (see Palmer 1988 for review). For example, some species traditionally perceived as being intimately associated with bottom deposits in a South Carolina salt marsh and exhibiting little in the way of within site mobility have now been shown to be suspended into the water column and passively carried by erosional bottom shear currents (Palmer \& Gust 1985). With this in mind, a sampling strategy was employed to investigate shortterm fluctuations in abundance of various life history components of Parastenhelia megarostrum, with the null hypothesis being that changes in tide and light over a $24 \mathrm{~h}$ period have no effect on the ambient sediment density or population structure of this species. The interstitial species Paraleptastacus sp. collected along with $P$. megarostrum was similarly analysed.

\section{MATERIALS AND METHODS}

A single sampling station was occupied in an area known to support high densities of both epibenthic and interstitial harpacticoid copepods. The site, an intertidal sandbank (Mana Bank) in Pauatahanui Inlet, New Zealand $\left(41^{\circ} 06^{\prime} \mathrm{S}, 174^{\circ} 54^{\prime} \mathrm{E}\right)$, has been adequately described in other publications (see Hicks 1984, 1989). Tidal sea level change within the inlet is semidiurnal and near symmetrical with a mean spring range of $1.25 \mathrm{~m}$ and mean neap range of $0.4 \mathrm{~m}$. The bank is emergent for ca $6.10 \mathrm{~h}$ of each cycle, but local sea levels and tidal range are frequently influenced by meterological conditions.

Water levels over the sampling site during the high tidal phase were measured in the following way $A$ $1300 \mathrm{~mm}$ long clear acrylic tube $(12 \mathrm{~mm}$ internal diameter), with a $3 \mathrm{~mm}$ thick footing was held vertically in the water column with the foot seated level on the sediment surface. A $4 \mathrm{~mm}$ hole drilled through one wall of the tube, $10 \mathrm{~mm}$ from the footing, allowed water entry to the tube cavity. As water rose within the tube a small polystyrene ball placed inside the cavity floated up on the water surface allowing critical reading from a graduated scale etched on the outer side of the tube. The scale was graduated every $10 \mathrm{~mm}$.

Subsurface (ca $10 \mathrm{~cm}$ depth) tidal current speeds were estimated at flood and ebb as duration of flow between permanent markers. Two alloy stakes were emplaced vertically into the sediment aligned parallel to the direction of tidal flood and ebb. At all but one sampling event when tidal waters covered the sediment, 5 measurements of flow were made. A slightly buoyant $(70 \mathrm{~mm}$ diameter) spherical sponge was squeezed to absorb water and dropped $2 \mathrm{~m}$ upcurrent from the leading marker; a stopwatch was used to time its passage from this to the trailing stake. The 5 measurements were averaged to give mean subsurface flow $\left(\mathrm{cm} \mathrm{s}^{-1}\right)$ at each sampling. Boundary shear velocities were not determined.

Sampling spanned $24 \mathrm{~h}$ beginning at 09:38 h on 6 April 1989 and terminating at 10:30 h on 7 April, a time of new moon spring tides. Weather conditions were fine over this period with a large anticyclone covering the region. This brought calm, settled, cloudless weather with very light N-NW winds, changing half way through the period to light-moderate southerlies. Every $2 \mathrm{~h}, 4$ core samples were taken from the troughs of well-formed sand ripples (low tide), or rounded ripple depressions (high tide). Cores were taken with a brass corer of $23 \mathrm{~mm}$ internal diameter (area. $4.15 \mathrm{~cm}^{2}$ ), and placed immediately into plastic pots containing $70 \%$ alcohol and bengal red stain. During the high tide phase, samples were hand collected by diving. Earlier tests had established this technique as more efficient than remote sampling (Hicks unpubl.). All samples were decanted, sieved through a $63 \mu \mathrm{m}$ mesh, sorted and counted. Individuals of the dominant epibenthic species, Parastenhelia megarostrum, were allocated to life history category (copepodite, adult, reproductive), sexed and enumerated. Sample counts were adjusted to number $10 \mathrm{~cm}^{-2}$. Individuals of the interstitial species Paraleptastacus sp. were counted as a total.

All of these procedures were completed during each sampling interval. A total of 48 samples were analysed from the 12 sampling events. All samples taken during the high tidal phase were at a time of water movement (flooding, ebbing); no samples coincided with slack high water (high tide). For the purposes of subsequent analyses, samples taken during periods of immersion are regarded as 'high tide' samples. 'Low tide' samples refer to those taken when the sediment surface was exposed to air.

To determine if different stages in the life cycle are variably influenced by tidal flows, measurements of body size were undertaken. Body volumes of Parastenhelia megarostrum were approximated for each life 
history category as length $\times$ width $^{2}(\mathrm{~mm})$ with a conversion factor of 600, extrapolated from Warwick \& Gee (1984), regarded as appropriate for the body form of this species. Measurements were made on Copepodite III and used as an intermediate standard representing the 5 subadult copepodite stages. Egg sac volumes were assessed independently and added to body volumes of the ovigerous female. Body volumes (nl) for each life history category were ranked against their own abundance in relation to state of the tide.

Because of the anticipated phase shift in tidal height with time, one set of 4 samples taken at high water/ night was advanced $1 \mathrm{~h}$ to remain within this period of the tide. Between sample set variability was not established as only one site was occupied and sampled in a temporal sequence. Individual samples were thus not treated as independent replicates of successive sampling times (sensu Hurlbert 1984). Instead, individual samples from each sample period were summed and means calculated. Departures in randomness of this sequence of measurements were determined with a runs test (Walpole \& Myers 1978), which detects trends or periodicities in data. Patterns were elucidated for the total population of both Parastenhelia megarostrum and Paraleptastacus sp. and separately for various life history categories of the former. The degree to which various life history categories of $P$. megarostrum cooccur in samples was assessed by product moment correlation coefficients on $\log _{10}(x+1)$ transformed values.

\section{RESULTS}

A summary of water depth over the sediment at various stages of the high tide and tidal current velocities at the sampling site are presented in Table 1. Subsurface current speeds over this site are consistent with those previously reported from the bottom of flood

Table 1. Water levels over intertidal sandbank at different phases of the high tide, with subsurface tidal flows, Mana Bank, Pauatahanui Inlet, April 1989

\begin{tabular}{|ccccc|}
\hline $\begin{array}{c}\text { Sample } \\
\text { no. }\end{array}$ & $\begin{array}{c}\text { Time } \\
(\mathrm{h})\end{array}$ & $\begin{array}{c}\text { Water } \\
\text { head } \\
(\mathrm{mm})\end{array}$ & Tide & $\begin{array}{c}\text { Subsurface flow } \\
\left(\mathrm{cm} \mathrm{s}^{-1}\right)\end{array}$ \\
\hline April 6 & & & & \\
1 & $09: 38$ & 630 & Flood & 36.1 \\
2 & $11: 40$ & 415 & Ebb & 31.6 \\
6 & $22: 05$ & 580 & Flood & 34.0 \\
April 7 & & & & \\
7 & $00: 10$ & 385 & Ebb & 25.8 \\
12 & $08: 25$ & 140 & Flood & 22.7 \\
\hline
\end{tabular}

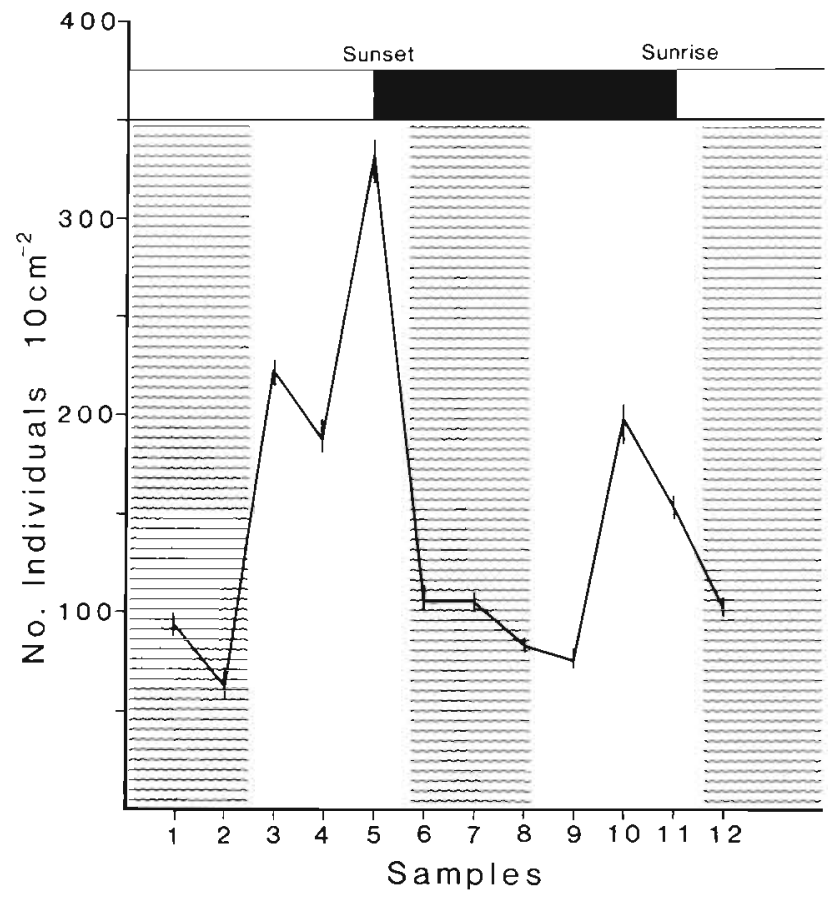

Fig. 1. Parastenhelia megarostrum. Mean number ( \pm SE) of individuals sampled bihourly from sediments during periods of tidal immersion (wave hatch) and emersion (clear). Period of daylight denoted by clear bar at top, night period darkened. Pauatahanui Inlet, 6-7 April 1989

channels elsewhere in the Inlet (Healy 1980). They are of a similar order to other studies (e.g. Palmer \& Gust 1985).

A total of 9 species of benthic copepods were identified during the course of this investigation. The overwhelmingly dominant species $(>98 \%)$ in samples were the epibenthic Parastenhelia megarostrum and the interstitial Paraleptastacus sp. Of these, the former was at all times more numerous than the latter. Only these 2 species will be further addressed here.

Average sediment densities of Parastenhelia megarostrum are higher during periods of exposure than during periods of cover by tidal waters (Fig. 1). Abundances over the sampling period peaked $(\bar{x}=331.4$ $\left.10 \mathrm{~cm}^{-2} \pm 196.3\right)$ at a time coinciding ( $\pm 15 \mathrm{~min}$ ) with sunset. There is a suggestion that densities increase toward the middle of the low water period (as predicted from tide tables) on both low tide occasions sampled. The second phase (Sample Groups 9 to 11) particularly allows for analysis, as samples coincide with late ebb, slack low water and early flood, while the sampling site remained exposed. There were on average significantly more individuals sampled at a time of predicted slack low water than sampled immediately previously (Kruskal-Wallis, $H=4.08, \mathrm{p}<0.05$ ), but not so immedi- 
ately following $(H=0.75, p>0.05)$. A similiar pattern is evident in the first low tide phase (Sample Groups 3 to 5), but between-sample variability is high, obscuring any significant trend.

The population is dominated by copepodites, averaging $49 \%$, but reaching a maximum of $74 \%$ of the total density during the study. They clearly contribute most to overall trends in the data (Fig. 2) and are most abundant at sunset and in samples circumscribing the period of sunrise (Fig. 2).

Adult males, females and ovigerous females all attain

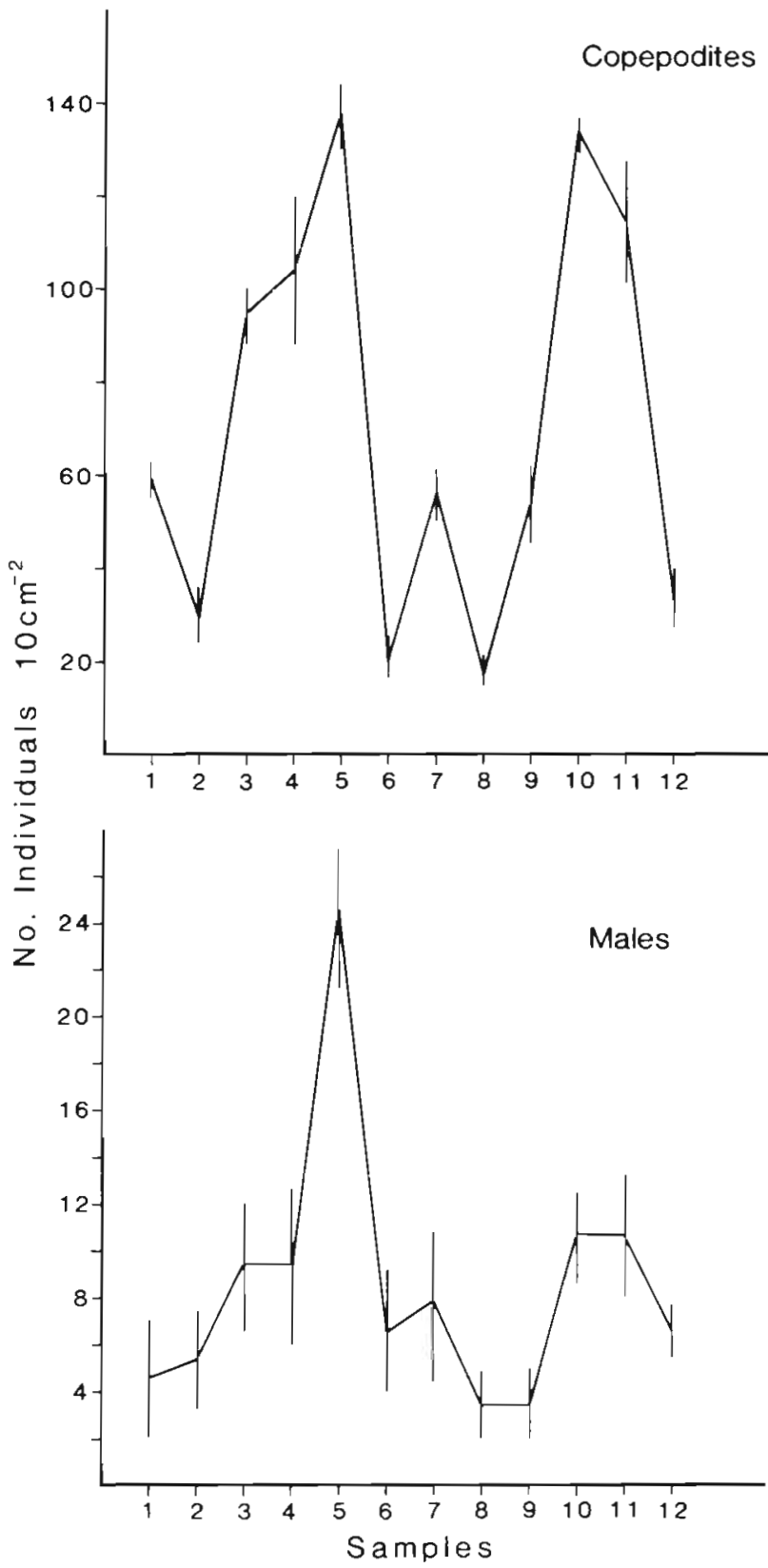

Fig. 2. Parastenhelia megarostrum. Mean number ( $\pm \mathrm{SE}$ ) of copepodites and adult males sampled

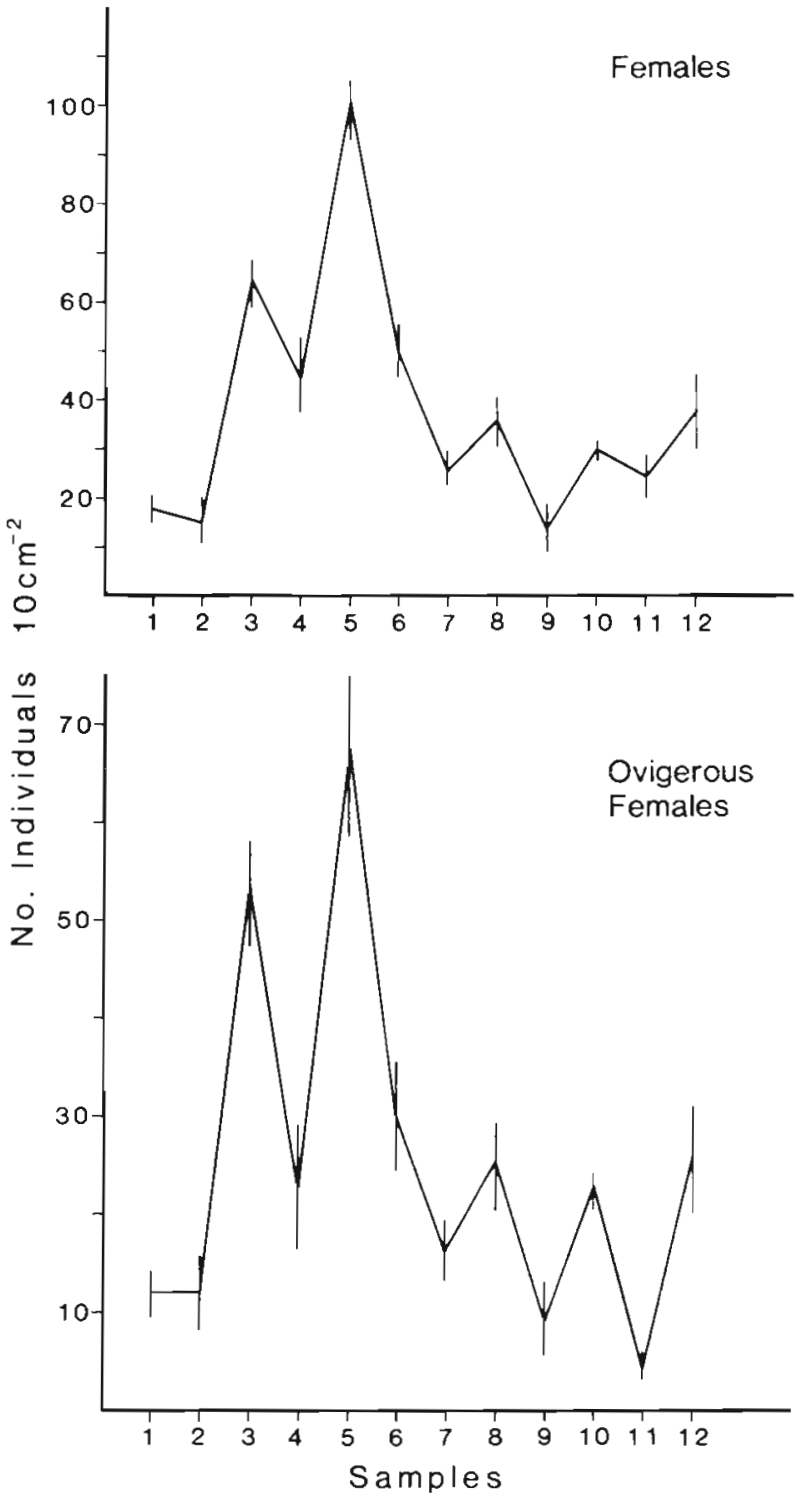

Fig. 3. Parastenhelia megarostrum. Mean number ( \pm SE) of adult females and egg bearing (ovigerous) females sampled

highest sediment abundances at sunset, with males only indicating a bimodal trend similar to copepodites (Fig 2). There is a clear difference in female abundances in samples taken during daytime low tide compared with those at night (Fig. 3).

Runs tests confirm some of these trends. There were no consistent periodicities linked to night/day. In contrast there were significant $(p<0.05)$ departures from randomness in total abundance, copepodites and adult males, with trends coupled to periods of high/low tide. In each of these categories bottom abundances were significantly higher at low tide than high tide, both during the day and at night. Adult females with and without egg sacs demonstrated more random abun- 
Table 2. Parastenhelia megarostrum. Level of association (Pearson $r$-correlation coefficients and calculated probabilities) among various life history categories. Pauatahanui Inlet, $1989 . \cdots p<0.001 ;{ }^{\cdots} p<0.01 ;{ }^{*} p<0.05$

\begin{tabular}{lllll|}
\hline & Copepodites & Males & Females & Ovigerous females \\
\hline Copepodites & $0.0064^{\cdots}$ & 0.735 & 0.255 & 0.052 \\
Males & 0.4236 & $0.0108 \cdot$ & 0.445 \\
Females & 0.8729 & 0.1471 & 0.703 & 0.848 \\
Ovigerous females & & $0.0005 \cdots$ & \\
\hline
\end{tabular}

dance patterns in relation to the tidal cycle. These observations suggest that tide is the stronger cue than diel events in influencing sediment abundances of copepodites and males, which together contribute most to total population variation.

Average body volumes (nl) for copepodites were 2.16 , adult males 2.46, adult females 6.84 and ovigerous females 7.80 . Individuals with the smallest generalized body size (volume) exhibited the most consistent tide related fluctuations, being less abundant in sediment cores during high tide than larger individuals.

A strong positive association between females with and without egg sacs was revealed in core samples integrating the entire sampling period (Table 2). Significant associations between adult males and females, but more particularly adult males and copepodites, is consistent with earlier findings for this species when sampled during low water only (Hicks 1984).

There were no consistent differences for Paraleptastacus sp. between tidal height or day/night. Abundance fluctuations between sampling occasions were extreme (Fig. 4).

\section{DISCUSSION}

This is the first report investigating the influence of tide and light, 2 primal environmental cues, on the population structure of an intertidal meiobenthic copepod. Previous intertidal and subtidal studies have relied for their interpretation on abundance of total taxa, viz. nematodes or copepods, or of individual species. Apart from Kern's (1990) investigation of the effects of subtidal flow fields on copepods near Mustang Island, Texas (USA) none has addressed what impact these variables might have on various life history categories within a species.

The present study, while of limited duration, does nevertheless suggest that within a single species population, short-term temporal differences exist in the response by juveniles, adults and reproductive individuals to regular predictable daily variations in the environment. This conclusion may at first seem unremarkable, but just as surely as results from recent experiments with seagrass-dwelling taxa indicate (Bell et al. 1988, 1989), studies only focusing on total abundance of taxa and not treating each life history stage independently can overlook important internal behaviour patterns.

Responses to tidal and diel cycles varied both between the 2 species investigated and also within the dominant species, Parastenhelia megarostrum. The abundance of Paraleptastacus sp. in cores was unrelated to measured changes in state of tide or light. Variation in density of this species over the time scale of sampling would seem to be linked to factors other than those currently under consideration.

In general, lowest abundances of the total Parastenhelia megarostrum population were found during periods of immersion, with highest abundance found when the sediment was exposed. Juveniles and adult males of $P$. megarostrum are the only components of the population to consistently demonstrate any

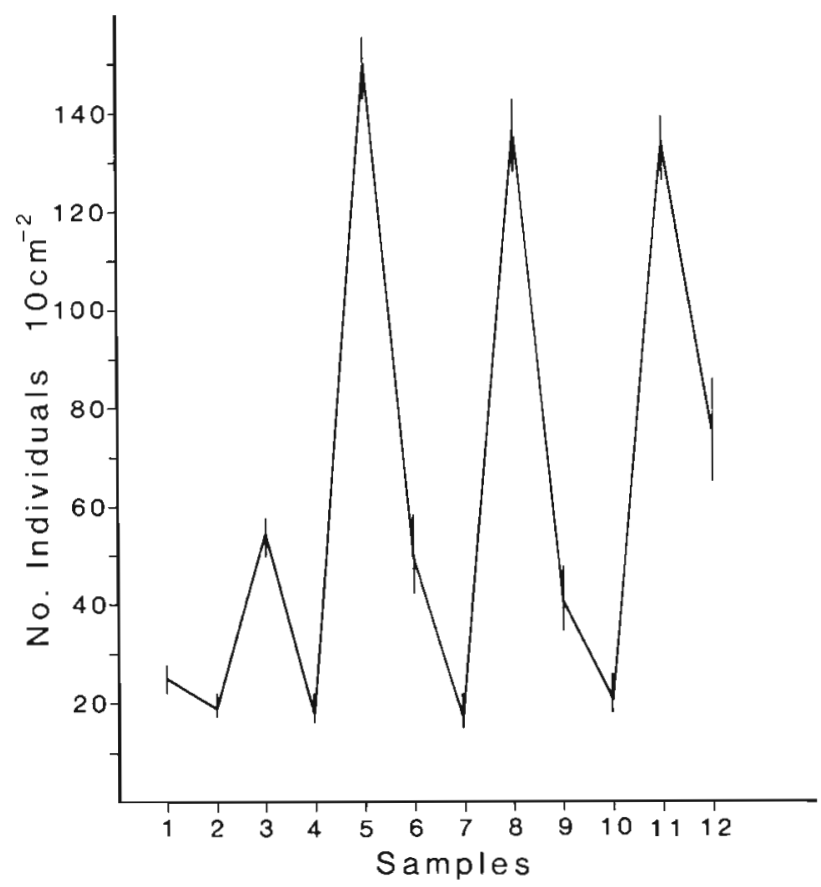

Fig. 4. Paraleptastacus sp. Mean number ( \pm SE) of individuals sampled 
periodicity linked with tide. Day/night had no repeatable influence on abundance fluctuations in this species; differences evident in adult and ovigerous females only occurred at one phase of the tide. The recognition that sediment abundance of $P$. megarostrum is in general lower during tidal immersion than during periods of low water exposure is consistent with a growing number of reports on other meiofaunal taxa (e.g. Palmer \& Brandt 1981, Fleeger et al. 1984, Coull \& Feller 1988, Armonies 1989, Feller et al. 1990). In these, densities on the substratum were highest with no overlying surface water and lowest during immersion when flooding and ebbing tidal currents were in operation. Clearly, tidal flow over unvegetated intertidal sediments is a highly significant factor influencing abundance patterns. It is now well known that many epibenthic species become transported into the overlying water column by bottom shear currents.

That components of the Parastenhelia megarostrum population were affected by tide, yet Paraleptastacus sp. was not, implies a differential propensity for erosion by these 2 species. Paraleptastacus sp. is an interstitial species living deeper in the sediment matrix (down to about $6 \mathrm{~cm}$ ), a vertical distribution probably mitigating removal by tidal flows. $P$. megarostrum is, however, a moderately sized species that is more superficial in its occupancy of bottom deposits. It does not actively swim into emergence traps during high water (Hicks 1986), and in situ stereomicroscope observations (Hicks 1988) have revealed that the smallest individuals, nauplii and copepodites particularly, are more conspicuous on the sediment surface than are the large females that tend to live about $1 \mathrm{~mm}$ or so deeper. Thus smaller individuals are predisposed to passive resuspension during the flood and ebb of the high water phase.

A priori, one would expect that the smallest and lightest individuals of a population would be the first to be suspended, show the greatest attrition from sediments, and, as a consequence, contribute most to the water column in flowing environments. Palmer \& Gust (1985), however, indicated that for the species they considered, erosion was not body size dependent. Their study revealed that relative to adults, resuspension rates by late stage nauplii and all copepodite stages was infrequent. Contrary results obtained here and by Kern (1990) suggest that sediment abundance variability is indeed flow/body size interactive. Copepodites are the smallest postlarval individuals in the $P$. megarostrum population, with average body volumes about one-third that of adult females. As smaller individuals have an increased surface area to volume ratio, it is reasonable to assume that they are most susceptible to erosion by boundary shear currents associated with local tidal flows. Consequently they contribute most to the observed population reductions from sediments during high water. Adults males are the only other group to show a similar trend to copepodites. This is perhaps not surprising considering their only slightly higher body volumes (see 'Results'), and that they, like copepodites, are more surficial in their occupancy of the sediment than are adult females.

Both sets of samples covering the low water phase (Samples 3 to 5, 9 to 11) reveal sediment abundances increasing to peak at times of predicted slack low water (Fig. 1). One possible explanation for this is that as the tide recedes, individuals previously disturbed by immersion, or returning to the bottom from the water column (Bell et al. 1989), progressively reassort themselves during tidal exposure. Increasing aggregation in sediment ripple troughs around possible resource patches such as food (Hicks 1984, 1989), may predicate high sample densities. It would appear that prior to reimmersion, these contagious patterns break down, perhaps as a response to tidal wetting of sediments by changes in pore water, or as a consequence of alterations in dispersion of putative food organisms (Decho \& Fleeger 1988a). Adult and ovigerous females, moreover, are considerably less abundant in samples taken at night-time low tide than during the day (Fig. 3). Sediment diatoms are known to cease migration to the surface in darkness and to be less strongly aggregated (Round \& Palmer 1966, Harper 1969). which might explain not only the abundance differences with light for adults, but also indicate ontogenetic feeding differences for copepodites (Decho \& Fleeger 1988b). Further work is needed to test these notions, but they point to yet another example of the highly dynamic nature of meiobenthic populations over small spatio-temporal scales.

Palmer (1988) has presented a conceptual model attempting to integrate taxonomic composition of the community, hydrodynamics, aboveground structure and disturbance to explain the relative importance of active vs passive mechanisms leading to the water column occurrence of typically meiobenthic taxa. She proposed that meiobenthic copepods part company with the bottom by 2 essentially different pathways that are habitat dependent. In vegetated systems where boundary flows are reduced because of the drag exerted by aboveground plant structure, copepods actively swim into the water column. Alternatively in high flow, unvegetated sand and mudflat systems, resuspension is a passive process linked closely to the strength of tidal currents. Whichever pathway that is utilized by individuals leaving the substratum, the net effect is the same, viz. that a proportion of normally benthic organisms end up in the water column for limited periods of time. Here they are presented with opportunities for small scale dispersal and to elicit premating contacts (Bell et al. 1988, Kern 1990), yet they 
may become increasingly exposed to removal by midwater predators. The evolutionary consequences of this process become powerfully focused when midwater events such as these are interpreted as contributing to outbreeding and gene dispersal. For benthic brooding organisms like harpacticoids, this would be an important way of maintaining genetic integrity.

Acknowledgements. Susan Bell and Bruce Coull have each read and provided helpful suggestions on the manuscript. I thank the management of the Marina Motor Lodge, Paremata, for permission to use their premises as a laboratory. In particular, I am grateful to Frank and Leonie Keenan for allowing me to set up microscopes in their suite and for food and liquid refreshments through the night.

\section{LITERATURE CITED}

Armonies, W (1988). Physical factors influencing active emergence of meiofauna from boreal intertidal sediment. Mar. Ecol. Prog. Ser. 49: 277-286

Armonies, W. (1989). Meiofaunal emergence from intertidal sediment measured in the field: significant contribution to nocturnal planktonic biomass in shallow waters. Helgoländer Meeresunters. 43: 29-43

Bell, S. S., Hicks, G. R. F., Walters, K. (1988). Active swimming in meiobenthic copepods of seagrass beds: geographic comparisons of abundances and reproductive characteristics. Mar Biol. 98: 351-358

Bell, S. S., Hicks, G. R. F., Walters, K. (1989). Experimental investigations of benthic reentry by migrating meiobenthic copepods. J. exp. mar. Biol Ecol. 130: 291-303

Bell, S. S., Sherman, K. S. (1980). Tidal resuspension as a mechanism for meiofauna dispersal. Mar. Ecol. Prog. Ser 3: $245-249$

Boaden, P. J. S., Platt, H. M. (1971). Daily migration patterns in an intertidal meiobenthic community. Thalassia jugosl. 7 . $1-12$

Coull, B. C. (1985a). Long-term variability of estuarine meiobenthos: an 11 year study. Mar. Ecol. Prog. Ser. 24: 205-218

Coull, B. C. (1985b). The use of long-term biological data to generate testable hypotheses. Estuaries 8: 84-92

Coull, B. C., Feller, R. J. (1988). Site-to-site variability in abundance of meiobenthic copepods along a tidal gradient over 24 hours. Hydrobiologia 167/168: 477-483

Decho, A. W (1988). How do harpacticoid grazing rates differ over a tidal cycle? Field verification using chlorophyllpigment analysis. Mar Ecol. Prog. Ser 45: 263-270

Decho, A. W., Fleeger, J. W. (1988a). Microscale dispersion of meiobenthic copepods in response to food-resource patchiness. J. exp. mar Biol. Ecol. 118: 229-243

Decho, A. W. Fleeger, J. W. (1988b). Ontogenetic feeding shifts in the meiobenthic harpacticoid copepod Nitocra lacustris. Mar. Biol. 97: 191-197

Feller, R. J., Coull, B. C., Hentschel, B. T (1990). Meiobenthic copepods: tracers of where juvenile Leiostomus xanthurus (Pisces) feed? Can. J. Fish. Aquat. Sci. 47: 1913-1919

Fleeger, J. W., Chandler, G. T., Fitzhugh, G. R., Phillips, F. E. (1984). Effects of tidal currents on meiofauna densities in

This article was presented by R. M. Warwick, Plymouth, U.K. vegetated salt marsh sediments. Mar Ecol. Prog. Ser 19 $49-53$

Harper, M. A. (1969). Movement and migration of diatoms on sand grains. Br. phycol J. 4: 97-103

Healy, W. B. (ed.) (1980). Pauatahanui Inlet - an environmental study. New Zealand Dept of Scientific and Industrial Research, Wellington, DSIR Info. Ser 141

Heip, C. (1979). Density and diversity of meiobenthic copepods: the oscillatory behaviour of population and community parameters. In: Naylor, E., Hartnoll, R. G. (eds.) Cyclic phenomena in marine plants and animals Pergamon Press, Oxford, p. 43-47

Heip, C. (1980). Meiobenthos as a tool in the assessment of marine environmental quality. Rapp. P.-v. Réun. Cons. int. Explor. Mer. 179: 182-187

Hicks, G. R. F. (1984). Spatio-temporal dynamics of meiobenthic copepod and the impact of predation-disturbance J. exp. mar. Biol. Ecol. 81: 47-72

Hicks, G. R. F. (1986). Distribution and behaviour of a meiofaunal copepods inside and outside seagrass beds. Mar Ecol. Prog. Ser. 31: 159-170

Hicks, G. R. F. (1988). Sediment rafting: a novel mechanism for the small-scale dispersal of intertidal estuarine meiofauna. Mar. Ecol. Prog. Ser. 48: 69-80

Hicks, G. R. F. (1989). Does epibenthic structure negatively affect meiofauna? J. exp. mar. Biol. Ecol. 133: 39-55

Hurlbert, S. H. (1984). Pseudoreplication and the design of ecological field experiments. Ecol. Monogr. 54: 187-211

Jacoby, C. A., Greenwood, J. G. (1988). Spatial, temporal, and behavioural patterns in emergence of zooplankton in the lagoon of Heron Reef, Great Barrier Reef, Australia. Mar. Biol. 97: 309-328

Jacoby, C. A.. Greenwood, J. G. (1989). Emergent zooplankton in Moreton Bay, Queensland, Australia: seasonal, lunar, and diel patterns in emergence and distribution with respect to substrata. Mar. Ecol. Prog. Ser. 51. 131-154

Kern, J. C. (1990). Active and passive aspects of meiobenthic copepod dispersal at two sites near Mustang Island, Texas. Mar Ecol. Prog. Ser. 60: 211-223

Palmer, M. A. (1988). Dispersal of marine meiofauna: a review and conceptual model explaining passive transport and active emergence with implications for recruitment Mar Ecol. Prog. Ser. 48: 81-91

Palmer, M. A., Brandt, R. R. (1981). Tidal variation in sediment densities of marine benthic copepods. Mar. Ecol. Prog. Ser 4: $207-212$

Palmer, M. A. Gust, G. (1985). Dispersal of meiofauna in a turbulent tidal creek. J. mar. Res. 43: 179-210

Round, F. E., Palmer, J. D. (1966). Persistent, vertical-migration rhythms in benthic microflora. II. Field and laboratory studies on diatoms from the banks of the River Avon. J. mar. biol. Ass. U.K. 46: 191-214

Walpole, R. E., Myers, R. H. (1978). Probability and statistics for engineers and scientists. MacMillan Publishing, New York

Walters, K. (1988). Diel vertical migration of sediment-associated meiofauna in subtropical sand and seagrass habitats. J. exp. mar. Biol. Ecol. 117: 169-186

Walters, K (1991). Influences of abundance, behaviour, species composition, and ontogenetic stage on active emergence of meiobenthic copepods in subtropical habitats. Mar Biol. 108: 207-215

Warwick, R. M., Gee, J. M. (1984). Community structure of estuarine meiobenthos. Mar. Ecol. Prog. Ser 18: 97-111

Manuscript first received: March 11, 1992

Revised version accepted: August 3, 1992 